\title{
DATING HYDROLOGIC AND GEOMORPHIC CHANGE USING DENDROCHRONOLOGY IN TULLY VALLEY, CENTRAL NEW YORK: A SUMMARY
}

\author{
WILLIAM M. KAPPEL ${ }^{1}$ * \\ ${ }^{1}$ US Geological Survey, Emeritus, Ithaca, NY 14850, USA
}

\begin{abstract}
This report summarizes the results of three case studies where dendrochronology was used to evaluate hydrologic and geomorphic change in parts of Tully Valley, in central New York, over the past 150 years. The case studies evaluate 1) the changes in water quantity and quality in a wetland area several miles north of an area of former solution-brine mining, 2) the development of recent bedrock fractures above former solution brine-mining areas, and 3) the development and timing of landslide movement. The advantage of contemporary dendrochronology is that tree-ring analysis can provide a background of hydrologic and geomorphic change when no direct documentation or data are available.
\end{abstract}

Keywords: Tully Valley, New York, dendrogeomorphology, tree-rings, forensic hydrology.

\section{GEOLOGIC AND MINING HISTORY OF TULLY VALLEY}

Tully Valley is a $10-\mathrm{km}$-long glacial trough that begins near the southern part of the Onondaga Creek Valley, ca. $24 \mathrm{~km}$ south of Syracuse, New York (Figure 1). The valley was carved into Silurian and Devonian bedrock (Kappel and Miller 2003) and has undergone multiple periods of glacial advance and retreat during the Pleistocene. The glacial erosion has widened and deepened the valley and has left deposits of clay, silt, sand, gravel, and till of variable thickness within the valley and along the valley walls (Kappel and Miller 2003).

The bedrock at the valley sides is Middle Devonian Hamilton Group shale and the floor of the bedrock valley is Lower Devonian Helderberg Group limestone and dolostone. Upper Silurian Salina Group shales and evaporite deposits (gypsum and halite) are $c a .365$ to $425 \mathrm{~m}$ below land surface at the southern end of the Tully Valley and were solution-mined for the production of soda ash and other chemicals beginning in the late 1880s through the late 1980s (Kappel 2000).

*Email: wkappel@usgs.gov
These areas of halite utilization are referred to as brine fields (Figure 1).

During the 1880s through the 1950 s, solution-brine mining injected surface water in boreholes drilled into the $45 \mathrm{~m}$ thick halite beds. No barrier pillars or walls of halite remained during the mining process, which subsequently caused fracturing of the overlying shale and limestone and eventually caused land-surface subsidence. This subsidence closed the east brine field in the late 1950s. From the 1960s until the brine operation closed in the mid-1980s, brine was pumped from just the west brine field wells and these wells were not supplemented by surface-water injection. The early brine wells generally were unlined according to the records of the brine-mining company and ca. 50 percent of the injected water was "lost" and did not return to the surface (Kappel et al. 1996). Some of the "lost" water, most likely brine, entered the valley-fill glacial deposits from the buried bedrock valley walls and the rest flowed updip (northward) in bedrock fractures, some of which was suspected to be the source of brackish water flowing from some springs along the western valley wall, north of the former brine fields (Yanosky and Kappel 1997b). 


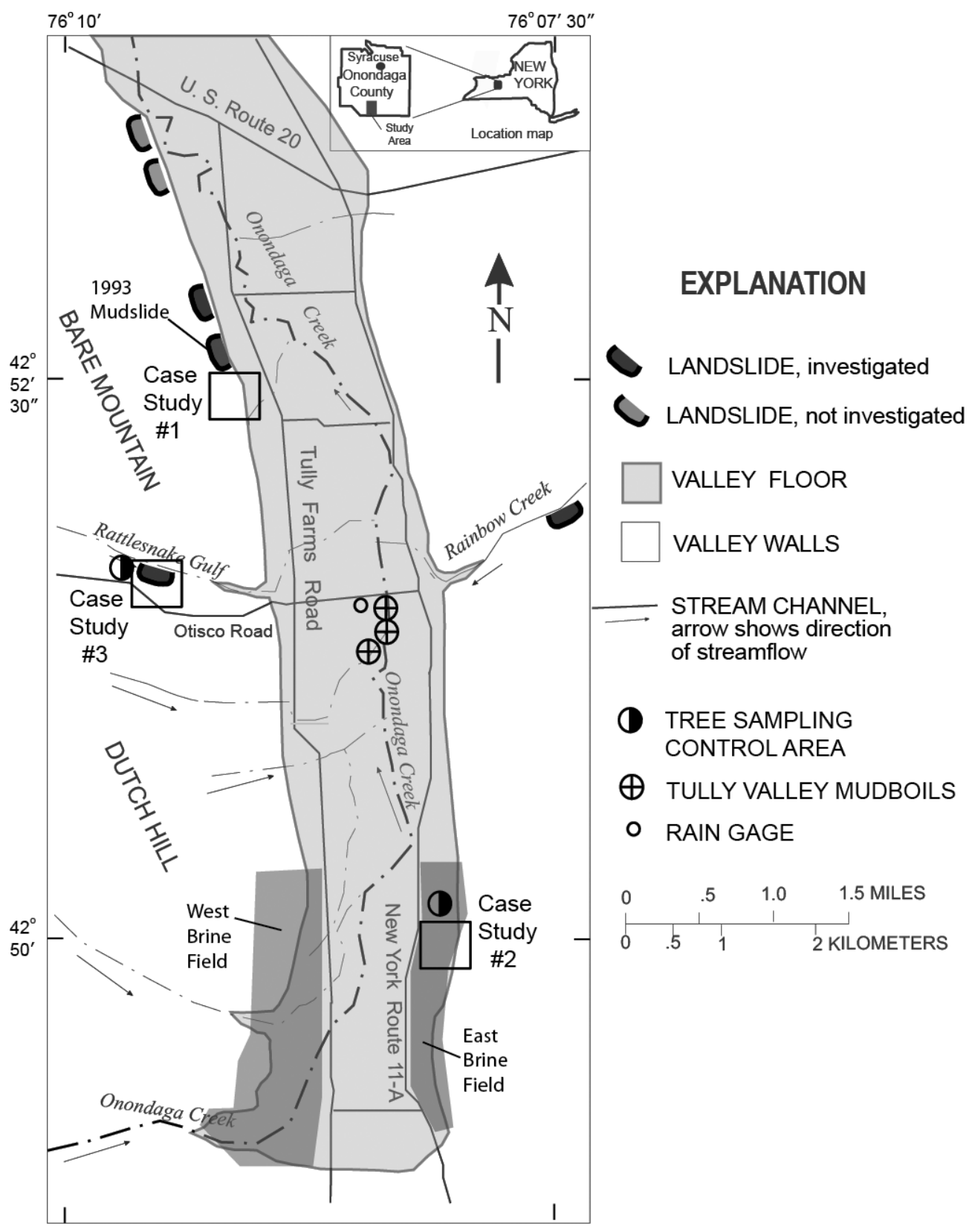

Figure 1. Map of the Tully Valley showing physiographic and hydrogeologic features.

Tully Valley is geologically active and has several unique hydrogeologic features that have caused parts of the valley to change. The Tully Valley mudboils (Figure 1) or mud volcanoes have been documented for over 100 years - from an 1899 newspaper report through recent hydrogeologic studies (Kappel et al. 1996; Kappel 2009).
Through the use of radiocarbon $\left({ }^{14} \mathrm{C}\right)$ age-dating of organic material (wood and peat), the natural occurrence of mudboils and associated landsurface subsidence can be documented back over 1500 years in this part of the valley.

In April 1993, the largest landslide in New York since the early 1900s occurred on the west 


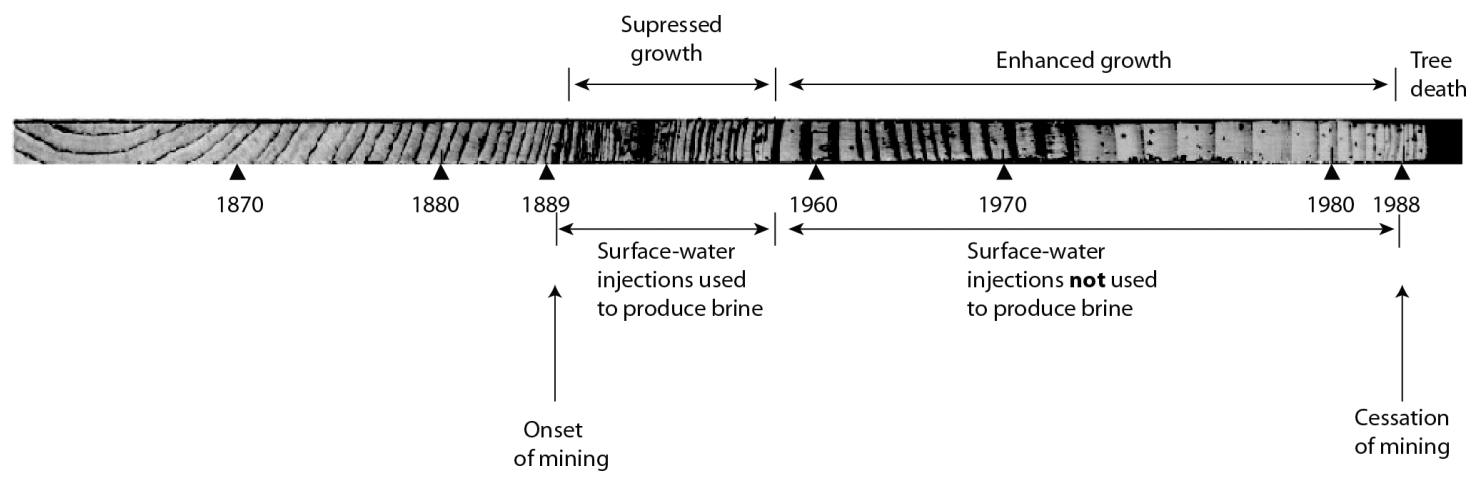

Figure 2. Increment boring of the oldest tree within the study wetland showing tree-ring widths and a comparison to the history of changes in brine mining several miles south of the study wetland.

wall of Tully Valley near Bare Mountain (Fickies 1993), ca. $2.4 \mathrm{~km}$ from the mudboil area (Figure 1). Several other landslides have occurred along the western valley wall (Pair et al. 2000) with several of these dated to 11,200 and $7000 \mathrm{cal}$ yr B.P. (calibrated years before present) (Kappel and Teece 2007). More recent landslide activity has been documented in the tributary valleys of Tully Valley (Figure 1) by Tamulonis et al. (2009) and Tamulonis and Kappel (2009). Finally, recent subsidence and bedrock fracturing adjacent to the brine fields, associated with solution brine mining has been documented (Hackett et al. 2009). Although the valley is still undergoing physical change (landslides, mudboil-related subsidence, and bedrock fracturing), data documenting these past changes, be they natural or anthropogenic, are lacking, hence the need to use as many different approaches to understand the dynamic nature of this valley.

\section{CASE STUDY 1 - TREE RINGS RECORD THE PAST 130 YEARS OF HYDROLOGIC CHANGE}

Local residents indicated that several years prior to the 1993 mudslide they had noticed an increase in stream flow and a decrease in water quality (increased salinity) in a stream they used as their water supply (Yanosky and Kappel 1997b). The stream is sourced in a small wetland south of the 1993 mudslide area wherein both fresh and brackish-water springs discharge from the base of the hillside to the wetland and stream.
The wetland was visited by the author after the 1993 mudslide and had many moss-covered hummocks with scattered alder brush (Alnus rugosa (Du Roi) Spreng.), cat-tails (Typha sp.) and a small number of eastern white pines (Pinus strobus L.) growing poorly within the wetland area, with eastern hemlocks (Tsuga canadensis (L.) Carr.) found along the base of the hillside adjacent to the wetland (Yanosky and Kappel 1997a). Seventeen eastern white pine and eastern hemlock trees were cored and tree ages ranged from 22 to 129 years old. Their diameters ranged from $c a .18$ to $46 \mathrm{~cm}$ and the youngest tree had a diameter of $29 \mathrm{~cm}$ while the oldest had a diameter of only $34 \mathrm{~cm}$.

Examination of the tree rings (increment boring for the oldest tree shown in Figure 2), indicated that all trees grew quite well (relatively wide growth rings) during the mid-1860s to the late1880 s, after which growth slowed (very narrow growth rings) for $c a$. 70 years (early 1890s to the late 1950s), and then all trees began to grow vigorously for almost 30 years (early 1960s to the late 1980s), before growth slowed again in the 1990s (Yanosky and Kappel 1997a). When compared to the history of brine mining that occurred ca. $5.6 \mathrm{~km}$ to the south of this wetland, a similar pattern of hydrogeologic change was evident. The injection of freshwater to dissolve the halite beds in the brine field and the loss of $c a$. half this injected water (now a brine) is suspected to have fed some of the brackish springs discharging to this wetland, changing the hydrology and stressing tree growth, most likely because of prolonged flooding within the wetland (Yanosky and Kappel 1997a). 
In the late 1950s the east brine field was closed because of land-surface subsidence while the injection of fresh water in the west brine field was found to be unnecessary. Brine continued to be pumped from the western brine field, likely reducing the amount of groundwater flowing up the bedrock bedding planes and ultimately into the study wetland. This potential change in groundwater flow into the wetland would have resulted in these soils becoming drier, likely enhancing tree growth and tree-ring development. Although the drought of the mid-1960s may have contributed to these growth changes, the enhanced growing conditions persisted into the late 1980s, until the brine mining operation ceased. Water levels within the brine mining area in the late 1980s rose enough to reinitiate brackish water flow at the wetland springs, leading to suppressed growth of the remaining eastern white pine trees. However, the changes in growth were not consistent with all of the eastern white pine trees. It was observed that the trees closest to the brackish springs were under greater stress - needle crops in 1994 and 1995 showed yellowing and several of the trees died in subsequent years (Yanosky and Kappel 1997a). The episodes of suppressed and enhanced tree growth likely resulted from changes in the hydrology of the wetland over time, but changes in ring widths do not directly provide evidence for changes in water quality.

Trees can preserve evidence of changes in water quality, however, as specific ion concentrations within the rings are somewhat proportional to that of the water quality that supplied the trees (Cutter and Guyette 1993; Yanosky and Vroblesky 1995; Yanosky et al. 1995). In the study of the wetland eastern white pines, proton-induced X-ray emission (PIXE) analyses were performed on increment borings from five trees, which exhibited the common growth pattern explained above.

Trees cored in the central part of the wetland, closest to the brackish springs, had greater concentrations of chloride, sulfur, and iron in the heartwood section than in trees located farther away from the brackish springs. The sapwood of the central wetland trees also showed similar patterns in the suppressed (most recent) growth, but in the very outer rings the chloride content was
2-7 times greater than the heartwood growth (Yanosky and Kappel 1997a).

In summary, the assessment of ring widths for white pine trees in the wetland just south of the 1993 mudslide indicates that changes in water availability were likely related to brine-mining practices several miles away and the movement of salty water along bedrock bedding planes from the brine-mining area to this wetland. In addition, water-quality changes within the wetland were also detected through the use of PIXE analyses of the tree rings, whereby concentrations of past changes in water quality taken up by the tree roots had been preserved within the tree rings themselves, providing a historic record of water-quality change in this wetland.

\section{CASE STUDY 2 - TREE RINGS RECORD CONTEMPORARY BEDROCK FRACTURE DEVELOPMENT}

Solution mining of halite (rock salt) beds in the southern end of the Tully Valley ( $c a .1895$ to 1988) (discussed above) caused the overlying shale and limestone bedrock to slowly fracture and subside, eventually causing land-surface subsidence over the brined areas. The adjacent bedrock valley walls responded to the subsidence, and the resulting release of lateral support on the lower valley walls allowed bedrock fractures to open along the orientation of naturally formed joints in the surrounding bedrock (Hackett et al. 2009).

The opening of new bedrock fractures adjacent to the uphill perimeter of the east and west brine fields were first noted in reports to the Solvay Process Company (1950, 1960), but the rate of fracture opening is not well known. During the characterization of fractures adjacent to the two brine fields (Hackett et al. 2009), several trees were found growing over open fractures. A maple tree (Acer sp.) growing over an open fracture above the eastern brine field (Figure 3) was chosen to determine if the sequence of fracture development could be documented in the tree rings. The tree was removed from its position over the open fracture in order to collect several cross-sections a cross-sectional sample of the growth rings of the tree $c a$. a foot $(30 \mathrm{~cm})$ above the root collar 


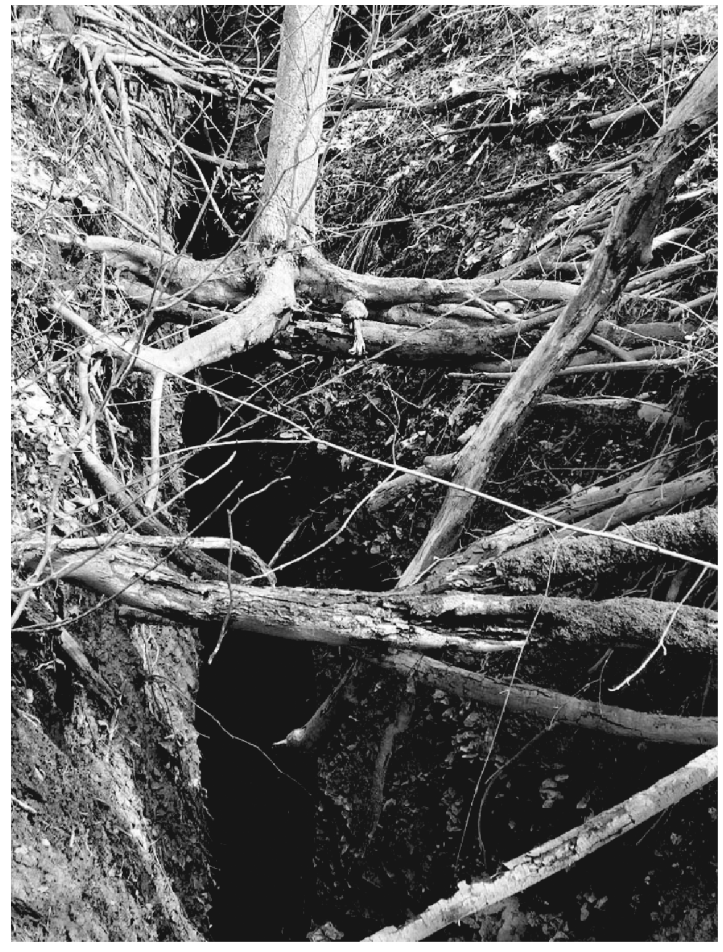

Figure 3. Picture of the sampled maple tree growing over an open bedrock fracture adjacent to the eastern brine field in the southern Tully Valley, NY.

and cross-sectional samples of the growth rings from the tree roots, one from near the tree trunk and the other furthest from the trunk at the airsoil interface.

The maple tree was almost $18 \mathrm{~cm}$ in diameter and was determined to be $c a$. 79 years old in 2006, indicating that it germinated $c a .1927$ or a year or two earlier. An assessment of the tree rings (Thomas Yanosky, US Geological Survey, written communication 2008) indicated that the growth of the tree had not been affected in any way, despite its position above the open bedrock fracture. The growth rings from 1985 until the tree was harvested in 2006 were wider than those of previous years suggesting that environmental conditions, most likely slowed fracture development and soil loss into the open bedrock fracture, allowed the tree to grow more vigorously, unaffected by the lack of soil to support the weight of the tree over the open fracture.

Maple trees have a thin bark, and are therefore susceptible to boring insects, which burrow under the bark and up along the cambial tissue just behind the bark where tree sap flows, leaving what is called pith channels (Brown 1913). Once the insect matures, it bores back out of the tree. What is left behind in each annual growth ring are the channels, and when viewed in cross-section, the channels appear as "pith flecks" in the annual growth rings (Figure 4). The exposure of the tree roots to air caused the roots to also be susceptible to the boring insects whereby the development of pith flecks along the tree roots could then be used to determine when they were exposed to the air and subsequent insect infestation.

Examination of the root cross-sectional samples indicated that the innermost root rings were devoid of any pith flecks but pith flecks were found in the outer growth rings. A root section close to the tree trunk had numerous pith flecks in annual growth rings dating back nearly 60 years, whereas a root section closer to where it re-entered the soil only had pith flecks dating back $c a$. 25 years. Using the pith flecks as a marker of root exposure to the air (soil falling into the opening bedrock fracture), the following time line of fracture development at this location was derived (Hackett et al. 2009).

ca. 1927 - The tree germinated in soil and the bedrock fracture was likely quite small with minimal soil displacement.

ca. 1947 - The fracture opened enough to allow soil to begin to fall away from beneath the tree, as noted in the Solvay Process Company reports (1950, 1960), exposing some tree roots closer to the tree trunk and allowing boring insects to begin leaving pith flecks in the roots annual rings.

ca. 1975 - Tree roots were exposed even further away from tree trunk, pith flecks not found as deep along this section of the tree root.

ca. 1986-2006 - Tree growth improved as seen in tree rings and roots - possibly indicative of slowed fracture development and more stable soil conditions.

In summary, the cross-sectional slabs of roots from a tree growing over an open fracture were used to date the opening of a bedrock fracture related to documented subsidence in the adjacent 
A

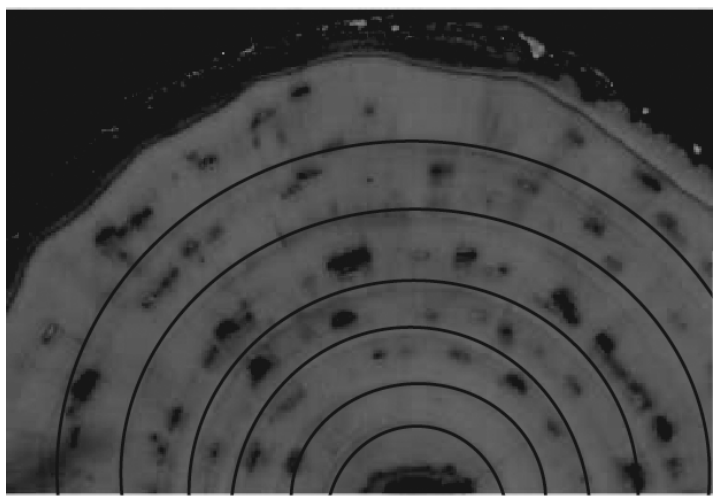

B

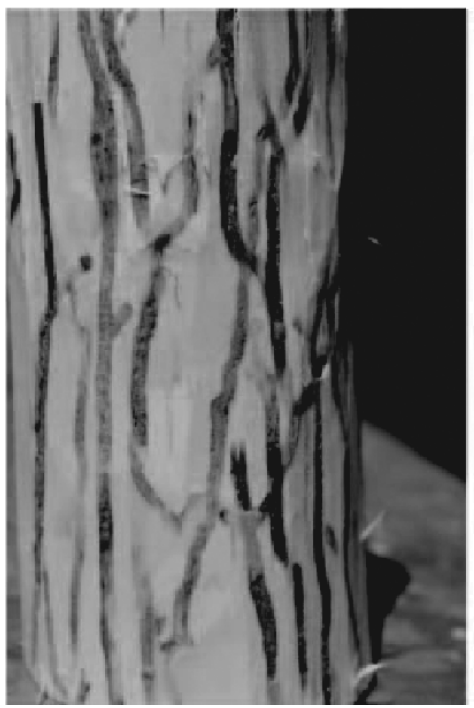

Figure 4. Example of pith flecks (dark blotches) in a young willow tree, showing: (A) their arrangement in individual annual rings from a cross-section of the tree (rings enhanced for clarity), and (B) pith channels along the tree trunk with the bark removed.

brine field. As soil fell into the opening fracture, the appearance of pith flecks within the roots indicated that they had been exposed to air as a fracture opened, and the locations of pith flecks along the roots were used to date the opening of the fracture over time. Vigorous growth observed in the final 20 years of tree rings (1986-2006) possibly indicates that slowed fracture development and soil loss have allowed the tree to grow vigorously, unaffected by the open fracture.

\section{CASE STUDY 3 - TREE RINGS RECORD CONTEMPORARY LAND SURFACE MOVEMENT AT THE RATTLESNAKE GULF LANDSLIDE}

The most active form of mass movement in Tully Valley are landslides in the main valley - the 1993 Tully Valley Landslide (Fickies 1993) and prehistoric landslides (Pair et al. 2000), and ongoing landslide activity in the two major tributary valleys to Tully Valley - Rainbow Creek and Rattlesnake Gulf (Tamulonis et al. 2009). The Rattlesnake Gulf landslide (Figure 1) has been studied more because of its ongoing subsidence activity and because the earliest aerial photography of central New York (1936-1937) clearly indicated landslide activity in the area of current land-surface movement (Tamulonis and Kappel 2009). Also, following the 1993 Tully Valley landslide, the USGS made a regional assessment of landslide activity in southern Onondaga County, centered on the 1993 landslide (Jäger and Wieczorek 1994). Numerous paleo-landslides were identified in the 1994 study, including one that encompasses, and is several times larger than, the ongoing landslide in Rattlesnake Gulf.

The current Rattlesnake Gulf landslide encompasses $c a .9 .3$ ha and consists of unconsolidated, laminated, glacio-lacustrine clay and silt that has undergone, and is still continuing to experience, mass movement and rotation (Tamulonis and Kappel 2009). To understand the history of this activity on the southern slope of Rattlesnake Gulf, a dendrogeomorphic assessment of trees (the use of dendrochronology to determine the timing of landform change) that have been affected by the landslide history was undertaken in 2006-2008 following the procedures of Sigafoos (1964), Hupp (1983), and Hupp et al. (1987) among other researchers. The premise of such an assessment is that landmass movement as slope failure would cause trees to rotate from their traditional vertical growth habit. The rotation of the tree from the vertical axis by landslides and soil creep can trigger a response in tree rings to add "reaction wood" to the downslope side of the tree causing the tree to bend upward (generally uphill) to compensate for the shift away from not being in a vertical position a process known as "geotropism". 


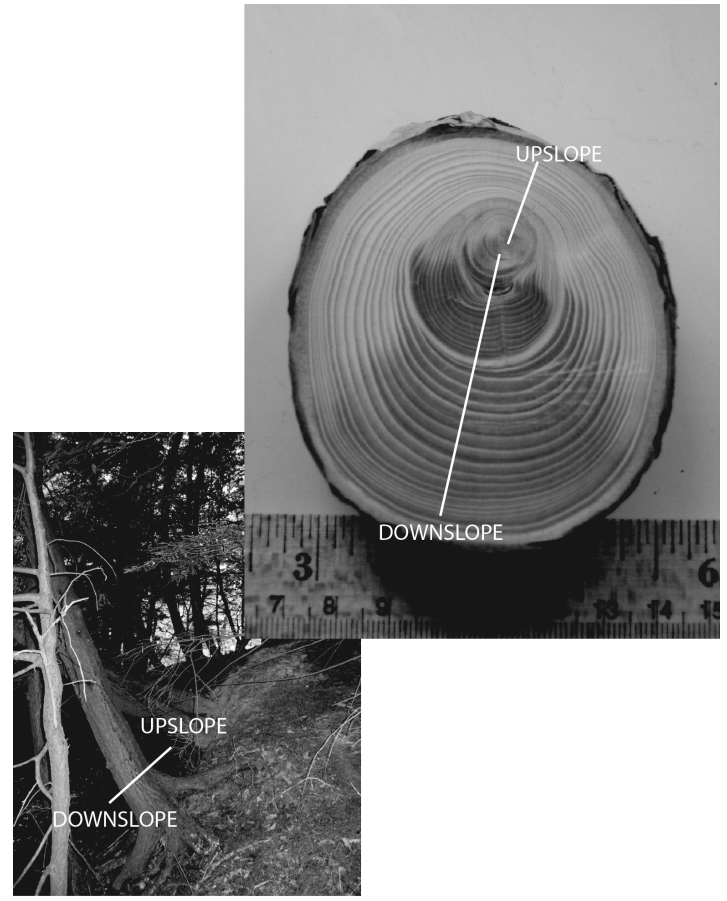

Figure 5. Picture of trees affected by a landslide causing Jshaped trunks, and a cross-section of a tree displaying asymmetric ring growth from a "J-shaped" eastern hemlock harvested at the Rattlesnake Gulf landslide area.

Tree-ring widths from 18 eastern hemlock trees were measured within the active landslide area (usually from trees with trunks having a "J"shaped appearance). An additional 12 control trees in areas outside the current landslide area, having no or a minor "J"-shaped trunks were also assessed (Figure 1; Tamulonis and Kappel 2009). Increment borings were taken from the downhill and uphill sides of each tree to compare the reaction wood - asymmetrical annual ring thicknesses formed when part of a woody plant is subjected to mechanical stress (Figure 5), to identify years of abrupt growth-rate change. Ring-width ratios (annual down-hill versus up-hill ring thicknesses) were computed for each annual ring of all trees. Based upon an analysis of trees from the control areas, only a ring-width ratio greater than 3 was used in subsequent eventresponse analysis (Schroeder 1978).

Although the oldest tree measured began to grow in 1877 , only a few of these very-old trees were present because of selective harvesting practices on the hillside and therefore ring-width ratios were computed from trees dating from $c a$. 1900 and younger. Summarizing the ring-width ratios in multiple trees can be used to develop an event-response curve (Schroeder 1978) to assist in analyzing the frequency of landslide-movement over time.

Results of the Rattlesnake Gulf dendrogeomorphic analysis (Tamulonis and Kappel 2009) indicated that various factors in the short and long term can predict landslide movement at this location. The best short-term precipitation predictor was a 3- to 5-year moving precipitation average, which provided a better estimate of landslide activity than annual precipitation. Also, multiple years of above-normal precipitation were more prone to cause landslide movement and the creation of reaction wood. In a similar sense, several consecutive months of consistently lessthan-normal precipitation followed by several consecutive months of excessively wet precipitation appear to increase landslide potential and reaction wood development.

In the longer term, both long-term precipitation/climatic patterns of alternating wet and dry periods, and harvesting of mature timber (removing root structure which stabilizes steep slopes) appear to be associated with landslide activity. The analysis of the long-term event-response curve for the Rattlesnake Creek area displayed an increasing number of 'events' (number of trees with reaction wood) occurring over the period of 1900 and 2000 - from just over 10 tree events per year in the early 1900 s to nearly 25 tree events per year in 2005. A similar increasing trend was found in relation to annual average precipitation over the same time period in this part of New York - from ca. $94 \mathrm{~cm}$ per year in 1900 to just over $102 \mathrm{~cm}$ per year in 2005. In regard to tree harvesting, an analysis of event-index residuals displayed a time-series response that can be tied to timber harvesting in the region over the 100 -year time span.

In summary, the assessment of ring-width variances for hemlock trees on the steep unconsolidated slopes of Rattlesnake Gulf was successfully used to determine more-active landslide periods (reaction wood development) over the 
past 100 years. The use of event-response-curve assessments also appears to be quite useful in determining what factors (precipitation amount and frequency and possibly tree harvesting) may contribute to landslides on these very steep slopes.

\section{CONCLUSION}

This report summarizes the techniques used to evaluate hydrologic and geomorphic change in the Tully Valley of central New York. These natural and anthropogenic changes were identified through: 1) dendrochronologic and physical assessment of tree rings in a wetland area several miles removed from a former brine-mining area that document groundwater quantity and quality changes, 2) pith-fleck analysis along newly exposed tree roots over an open bedrock fracture that document the rate and timing of the opening of a bedrock fracture caused by adjacent landsurface subsidence, and 3) dendrogeomorphic analysis of trees within and adjacent to a landslide that document the timing of landslide movement and possible sources of the mass movement. These novel dendrochronologic techniques were utilized to reconstruct the occurrence of hydrologic or geomorphic change at sites where there was no other documentation or data available to determine such change.

\section{REFERENCES CITED}

Aestello, J., 1971. Dendrochronological interpretation of geomorphic processes. Fennia 105:1-140.

Brown, H. P., 1913. Pith-Ray Flecks in Wood. US Department of Agriculture, Forest Service Circular 215, Washington, DC; $15 \mathrm{pp}$.

Cutter, B. E., and R. P. Guyette, 1993. Anatomical, chemical, and ecological factors affecting tree species choice in dendrochemistry studies. Journal of Environmental Quality 22:611-619.

Fickies, R. H., 1993. A large landslide in Tully Valley, Onondaga County, New York. Association of Engineering Geologists News 36:22-24.

Hackett, W. R., G. C. Gleason, and W. M. Kappel, 2009. LandSurface Subsidence and Open Bedrock Fractures in the Tully Valley, Onondaga County, New York. US Geological Survey Open-File Report 1188; 16 pp. http://pubs.usgs.gov/of/2009/ $1188 /$.

Hupp, C. R., 1983. Geo-botanical evidence of late Quaternary mass wasting in block field areas of Virginia. Earth Science Processes 8:439-450.
Hupp, C. R., W. R. Osterkamp, and J. L. Thornton, 1987. Dendrogeomorphic Evidence and Dating of Recent Debris Flows on Mount Shasta, Northern California. US Geological Survey Professional Paper 1396-B; 39 pp.

Jäger, S., and G. F. Wieczorek, 1994. Landslide Susceptibility in the Tully Valley Area, Finger Lakes Region, New York. US Geological Survey Open-File Report 94-0615; 1 plate.

Kappel, W. M., D. A. Sherwood, and W. H. Johnston, 1996. Hydrogeology of the Tully Valley and Characterization of Mudboil Activity, Onondaga County, New York. US Geological Survey Water-Resources Investigations Report 96-4043; 71 pp. http://ny.water.usgs.gov/pubs/wri/wri964043/.

Kappel, W. M., and T. S. Miller, 2003. Hydrogeology of the Tully Trough - Southern Onondaga County and Northern Cortland County, New York. US Geological Survey WaterResources Investigations Report 03-4112; 16 pp. http://ny. water.usgs.gov/pubs/wri/wri034112/.

Kappel, W. M., 2000. Salt Production in Syracuse, New York ("The Salt City") and the Hydrogeology of the Onondaga Creek Valley. US Geological Survey Fact Sheet FS 139-00; 8 pp. http://ny.water.usgs.gov/pubs/fs/fs13900/.

Kappel, W. M., and M. A. Teece, 2007. Paleoenvironmental Assessment and Deglacial Chronology of the Onondaga Trough, Onondaga County, New York. US Geological Survey Open-File Report 2007-1060; 12 pp. http://pubs.usgs.gov/of/ 2007/1060/.

Kappel, W. M., 2009. Remediation of Mudboil Discharges in the Tully Valley of Central New York. US Geological Survey Open File Report 2009-1173; 8 pp. http://pubs.usgs.gov/of/2009/1173/.

Pair, D. L., W. M. Kappel, and M. S. Walker, 2000. History of Landslides at the Base of Bare Mountain, Tully Valley, Onondaga County, New York. US Geological Survey Fact Sheet FS 019099; 6 pp. http://ny.water.usgs.gov/pubs/fs/fs19099/.

Schroeder, J. F. Jr., 1978. Dendrogeomorphological analysis of mass movement on Table Cliffs Plateau, Utah. Quaternary Research 9:168-185.

Tamulonis, K. L., W. M. Kappel, and S. B. Shaw, 2009. Causes and Movement of Landslides at Rainbow Creek and Rattlesnake Gulf in the Tully Valley, Onondaga County, New York. US Geological Survey Scientific Investigations Report 20095114; 18 pp. http://pubs.usgs.gov/sir/2009/5114/.

Tamulonis, K. L., and W. M. Kappel, 2009. Dendrogeomorphic Assessment of the Rattlesnake Gulf landslide in the Tully Valley, Onondaga County, New York. US Geological Survey Scientific Investigations Report 2009-5134; 14 pp. http:// pubs.usgs.gov/sir/2009/5134/

The Solvay Process Company, 1950. Tully brine well data and brief history. Memorandum (La-3-R): Syracuse, N.Y., Solvay Process Division - Allied Chemical and Dye Corporation, Syracuse, New York; 25 pp.

The Solvay Process Company, 1960. Investigation - Tully brine field - A history of development. Memorandum (8-JEM119), Syracuse, N.Y., Solvay Process Division - Allied Chemical and Dye Corporation; $17 \mathrm{pp}$.

Yanosky, T. M., and D. A. Vroblesky, 1995. Element analysis of tree rings in ground-water contamination studies. In Tree Rings as Indicator of Ecosystem Health, edited by T. E. Lewis, pp. 177-205. CRC Press, Boca Raton, Florida. 
Yanosky, T. M., C. R. Hupp, and C. T. Hackney, 1995. Chloride concentrations in growth rings of Taxodium distichum in a saltwater-intruded estuary. Ecological Applications 5:785-792.

Yanosky, T. M., and W. M. Kappel, 1997a. Effects of solution mining of salt on wetland hydrology as inferred from tree rings. Water Resources Research 33:457-470. 1997b. Tree Rings Record 100 Years of Hydrologic Change within a Wetland. US Geological Survey Fact Sheet FS 0057-97; 4 pp. http://ny.water.usgs.gov/pubs/fs/fs05797/.

Received 30 July 2012; accepted 20 March 2014. 